Research Article

\title{
Antiulcer Activity of Petroleum Ether and Ethanolic Extracts of Tuber of Pueraria tuberosa Roxb. in Albino Rats
}

\author{
Md. Rageeb Md. Usman*, Gautam P. Vadnere, Nikita P. Patel \\ Department of Pharmacognosy, Smt. Sharadchandrika Suresh Patil College of Pharmacy, Chopda, Maharashtra, India. \\ *Corresponding author's E-mail: rageebshaikh@gmail.com
}

Received: 18-10-2020; Revised: 15-12-2020; Accepted: 23-12-2020; Published on: 15-01-2021.

\begin{abstract}
Peptic ulcer is one of the most common gastrointestinal disorders and a major cause of morbidity. The incidence and prevalence of peptic ulcer has been increasing worldwide. Persisting peptic ulcer leads to complications like gastrointestinal bleeding, gastric perforation and pyloric obstruction. The complications further increase the morbidity and mortality. The objectives of this study were to evaluate the antiulcer activity of pet. ether and ethanolic extracts of tuber of Pueraria tuberose Roxb. in albino rats. Healthy wistar albino rat of male weighing about 120-180 grams were divided randomly into 4 groups $(n=6)$. The drugs were given as $0.1 \mathrm{ml}$ of $6 \%$ acetic acid once intrarectally. 7 day pretreatment with extract + on 8 th day $0.1 \mathrm{ml}$ of $6 \%$ acetic acid once intrarectally 3 $\mathrm{cm}$ from the anal margin (Iton, 2000), Drug treatment continued up to 10th day. Started on day of acetic acid treatment, given orally as a suspension containing $0.5 \%$ sodium CMC. Dose- $1.14 \mathrm{mg} / \mathrm{Kg}$ for 3 days. + On 8th day $0.1 \mathrm{ml}$ of $6 \%$ acetic acid once intrarectally. Parameters like free acid, gastric volume and ulcer index were observed. Result from ulcer index showed better protective effect by ethanol extract of Pueraria tuberose. Acetic acid caused increase in MPO level in blood and tissue up to $362 \mathrm{U} / \mathrm{ml}$ and $375 \mathrm{U} / \mathrm{mg}$, respectively. After treatment with ethanol extract of Pueraria tuberosa, the MPO level in blood and tissue was decreased significantly to $260 \mathrm{U} / \mathrm{ml}$ and $332 \mathrm{U} / \mathrm{mg}$ respectively. Significant dose dependent reduction was observed after treatment with individual extract.
\end{abstract}

Keywords: Pueraria tuberose, Tubers, anti-ulcer, Phytochemical, ethanolic extract.

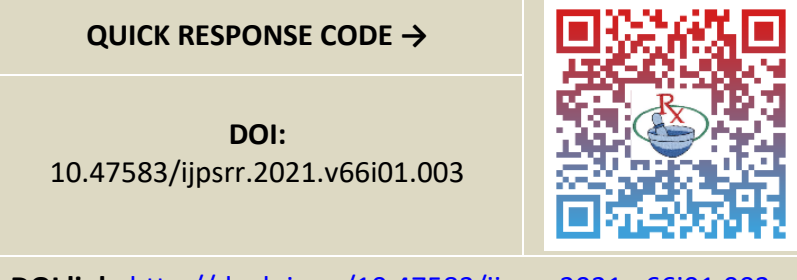

DOI link: $\underline{\text { http://dx.doi.org/10.47583/ijpsrr.2021.v66i01.003 }}$

\section{INTRODUCTION}

P

eptic ulcer being one of the most uncontrolled gastrointestinal problems representing a chief health hazards in terms of morbidity and mortality. The etiology of gastroduodenal ulcers is influenced by diverse aggressive and defensive factors for example acidpepsin secretion, mucosal barrier, mucus secretion, blood flow, cellular regeneration, and endogenous protective agents. ${ }^{1,2}$ Mucosal injury may happen when noxious factors "overwhelm" an intact mucosal protection or when the mucosal defense is somehow disrupted. ${ }^{3}$

Medicinal plants are being used by mankind as a source of medicine since immemorial time. Medicinal plants are generally known as "Chemical Goldmines" as it contain a variety of natural chemicals, which are acceptable to human being and animal systems ${ }^{4}$. A medicinal plant possesses curative properties due to the existence of various complex chemical substances of different composition known as secondary metabolites ${ }^{5}$. According to World Health Organization more than $80 \%$ of the World's population depends on traditional medicine for their primary healthcare requirements ${ }^{6}$. Approximately
$75 \%$ of the medicinally useful plant species produce in wild condition ${ }^{7}$. Pueraria tuber is sweet in taste and used in indigenous system of Indian medicine as antirheum atic, aphrodisiac, tonic for strength, diuretic and galactogogue ${ }^{8}$. Tubers are consumed as supplementary food and for birth control by assured Indian tribes ${ }^{9}$.

Pueraria tuberose Roxb., commonly known as kudzu ${ }^{10}$. Indian kudzu, or Nepalese kudzu ${ }^{11}$ is a climber with woody tuberculated stem. It is a climbing, coiling and trailing vine with large tuberous roots. The tubers are globose or potlike, about 25 centimeters ( 9.8 in) across and the insides are white, starchy and mildly sweet. Leaves are trifoliate and alternate, while the leaflets are egg-shaped, with round base and unequal sides. They are $18 \mathrm{~cm}$ (7.1 in) long and $16 \mathrm{~cm}$ (6.3 in) wide and are hairless above. Flowers are bisexual, around $1.5 \mathrm{~cm}$ (0.59 in) across and blue or purplish-blue in color. The fruit pods are linear, about 2-5 $\mathrm{cm}$ (0.79-1.97 in) long and constricted densely between the seeds. They have silky, bristly reddish-brown hair. Seeds vary from 3 to 6 in number. Indian Kudzu or Pueraria tuberosa Linn (Fabaceae) is an important medicinal plant of the Indian traditional system of medicine that is Ayurveda, and is mentioned in the Ayurvedic Pharmacopoeia of India under the name of Vidari. It is used in traditional medicine as a fertility control agent and as an aphrodisiac, cardiotonic, diuretic and galactogogue. It has exhibited antihyperglycemic, antihyperlipidemic, and antifertility in male rats, hepatoprotective, and antiimplantation activities ${ }^{12}$. It is a constituent of various formulations used as nutritive, diuretic, expectorants, and for the management of rheumatism, fever, and

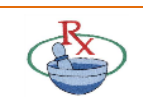


bronchitis ${ }^{13}$. P. tuberosa tubers are rich in isoflavonoids and the important phytoconstituents are puerarin, daidzein, genistein, puetuberosanol, and tuberosin ${ }^{14,15}$. During the past decade, interest in these isoflavonoids has increased considerably because of the beneficial effects proposed by epidemiologists, nutritionists, and food manufacturers ${ }^{16}$. These isoflavonoids could interact with milk proteins, namely, bovine serum albumin, ${ }^{17}$ casein micelle, ${ }^{18}$ and $\beta$-lactoglobulin, ${ }^{19}$ as has been reported in case of certain food and drug preparation containing soya isoflavonoids.

The Present work is to frame antiulcer activity of petroleum ether and ethanolic extracts of tuber of pueraria tuberosa roxb in albino rats. The plant of tuber of pueraria tuberosa Roxb. Figure 1.
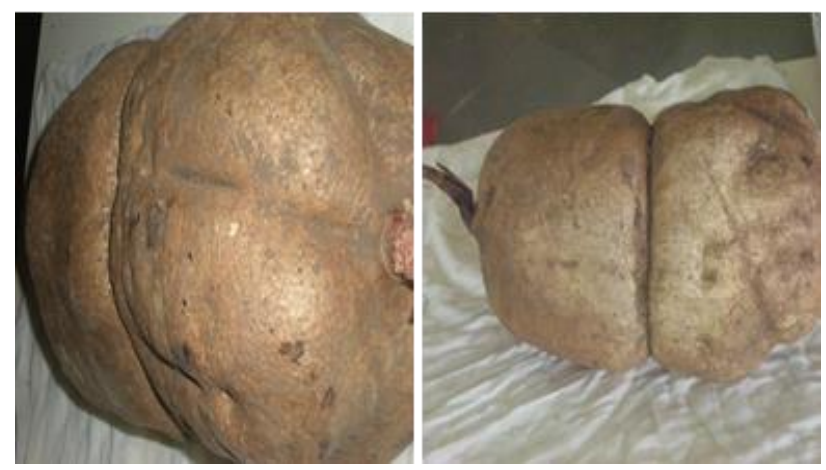

Figure 1: Tubers of Pueraria tuberose Roxb

\section{MATERIALS AND METHODS}

\section{Plant material}

The plant specimens for the proposed study were collected from Chopda Tehsil (Adawad) MS, India in the month of April 2019 care was taken to select healthy plants and for normal organs. The plant was authenticated by Botanical Survey of India (BSI), Pune, Maharashtra, India. A voucher specimen (No. NIPPUT1) was deposited at B.S.I., Pune, India.

\section{Animals}

Male wistar rats weighing about 120-180 gm were procured. The animals were kept under a conventional light regimen at room temperature (about $250 \mathrm{C}$ ) and humidity. Animals were housed in polypropylene cages and were allowed free access to standard laboratory feed and water. All the animals have been divided into four groups and placed in separate cages, each consisting of six animals. The animals were acclimatized to the laboratory condition for one week before the onset of experiment. The Institutional Animals Ethics Committee approved the protocol vid no. NIB/ IAEC/ 11-12/ 23

\section{Preparation of standard drug and extract solution:}

Solution of all extracts was prepared in Tween 80.

Test drug was dissolved in distilled water or in physiological salt solution.

Prednisolone was dissolved in physiological saline.

\section{Treatment of drug schedule (Table 1):}

Group I: Prednisolone Standard (5 mg/kg) p. o.

Group II: Petroleum ether $(100 \mathrm{mg} / \mathrm{kg})$ p. 0.

Group III: Ethanol (100 mg/kg) p. o.

Group IV: Negative Control (Distilled water containing 20 \% Tween 80) p. 0.

Table 1: Treatment of drug summary

\begin{tabular}{|l|l|}
\hline $\begin{array}{c}\text { Group } \\
\text { Control }\end{array}$ & \multicolumn{1}{c}{ Treatment } \\
\hline Test & $\begin{array}{l}7 \text { day pretreatment with extract + on } 8 \text { th day } \\
0.1 \mathrm{ml} \text { of } 6 \% \text { acetic acid once intrarectally } 3 \mathrm{~cm}\end{array}$ \\
& $\begin{array}{l}\text { from the anal margin (Iton, 2000), Drug } \\
\text { treatment continued up to 10th day. }\end{array}$ \\
\hline $\begin{array}{c}\text { Prednisolone } \\
\text { treatment }\end{array}$ & $\begin{array}{l}\text { Started on day of acetic acid treatment, given } \\
\text { orally as a suspension containing } 0.5 \% \text { sodium } \\
\text { CMC. Dose- } 1.14 \mathrm{mg} / \text { Kg for 3 days. + On 8th day } \\
\text { 0.1 ml of } 6 \% \text { acetic acid once intrarectally. }\end{array}$ \\
\hline
\end{tabular}

\section{Acetic acid-induced ulcer model ${ }^{20-24}$}

Study comprises of four different groups $(n=6)$ as summarized in treatment schedule. Test animals in group II to III receives seven day treatment of the different crude extract as mentioned in treatment schedule. On eighth day all animals receives $0.1 \mathrm{ml} 6 \%$ acetic acid intrarectally. Prednisolone treatment in standard group was started on the day of acetic acid treatment. Drug treatment in all groups was continued up to $10^{\text {th }}$ day. Control group receives only $0.1 \mathrm{ml} \mathrm{6 \%}$ acetic acid intrarectally on eighth day. After $48 \mathrm{hrs}$. of colitis induction mice were sacrificed by cervical dislocation and dissected upon to remove colon. $5 \mathrm{~cm}$ long piece of colon was flushed gently with saline, cut upon and scored for inflammation based on the macroscopic features. Tissues were fixed in $10 \%$ formalin saline and examined histopathologically. Biochemical evaluation of colon inflammation was done using assay of MPO activity and MDA activity.

Overnight fasted mice, anaesthetized by Pentobarbital sodium (55.00 mg/Kg i.p.) $0.1 \mathrm{ml}$ of $6 \%$ acetic acid once intrarectally. Allow to hang in air by holding tails for $1-2$ $\min$.

\section{Assessment of colitis severity}

The colonic samples from mice with colitis were shown to have severe mucous damage with edema, deep ulceration and hemorrhages. Oral administration of the petroleum ether and ethanol extracts of tubers of Pueraria tuberose, two days before infusion of acetic acid into the colon was found to prevent progression of colitis. In mice treated with extracts, colonic macroscopic scores and the total square of damage were significantly reduced compared with those in the vehicle treated colitis group.

\section{Histopathological observation:}

In the present study control group showed higher degree of pathological changes i.e. more damage noticed in this 
group. Methanol extract group showed considerable good reaction as compared to the other treated groups. Results shown Table 2.

Table 2: Histopathological observation

\begin{tabular}{|l|c|c|c|c|c|c|}
\multicolumn{1}{|c|}{ Treatment Group } & Ulceration & Hyperemia & Necrosis & Edema & $\begin{array}{c}\text { Cellular in } \\
\text { filtration }\end{array}$ & $\begin{array}{c}\text { Goblet cell } \\
\text { hyperplasia }\end{array}$ \\
\hline Standard Prednisolone $(5 \mathrm{mg} / \mathrm{kg})$ & ++ & ++ & ++ & ++ & ++ & ++ \\
\hline Pet. Ether extract $100 \mathrm{mg} / \mathrm{kg}$ & ++ & +++ & ++ & ++ & +++ & ++ \\
\hline Ethanol extract $100 \mathrm{mg} / \mathrm{kg}$ & ++ & ++ & ++ & ++ & ++ & ++ \\
\hline Control, Acetic acid $(-\mathrm{ve})$ & +++ & +++ & +++ & ++ & +++ & ++ \\
\hline
\end{tabular}

+: damage/ active changes up to less than $25 \%$; ++: damage/ active changes up to less than $50 \%$; +++: damage/ active changes up to less $75 \%$; ++++: damage/ active changes up to more than $75 \%$

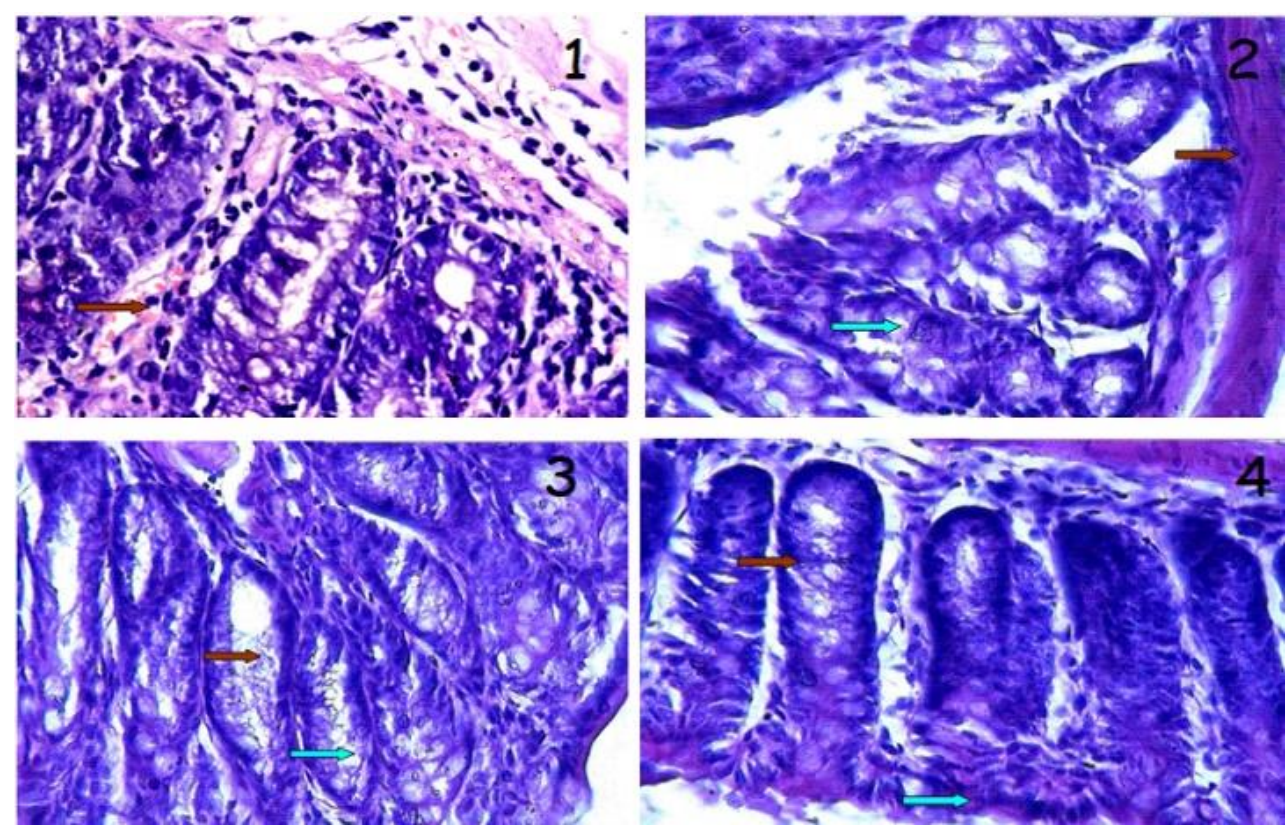

Figure 2: Histopathology results

1. Prednisolone treated group, Red arrow - Hemorrhages

2. Pet. ether extract treated group, Red arrow - Hemorrhages \& ulceration, Blue arrow - Cellular infiltration \& edema.

3. Ethanol extract treated group, Red arrow - Hemorrhages, Blue arrow - Leucocytic infiltration

4. -Ve treated group, Red arrow -hemorrhages \& ulceration, Blue arrow - Leucocytic infiltration

Table 3: Determination of Ulcer Index

\begin{tabular}{|l|c|c|}
\hline \multicolumn{1}{|c|}{ Treatment Group } & $\begin{array}{c}\text { Ulcer } \\
\text { Index }\end{array}$ & $\begin{array}{c}\text { Percent Ulcer } \\
\text { Protection }\end{array}$ \\
\hline Prednisolone $(5 \mathrm{mg} / \mathrm{kg})$ & 2.62 & 45.60 \\
\hline Pet. Ether extract $(100 \mathrm{mg} / \mathrm{kg})$ & 3.58 & 20.61 \\
\hline Ethanol extract $(100 \mathrm{mg} / \mathrm{kg})$ & 2.10 & 56.74 \\
\hline Acetic acid (negative) & 3.96 & 00.00 \\
\hline
\end{tabular}

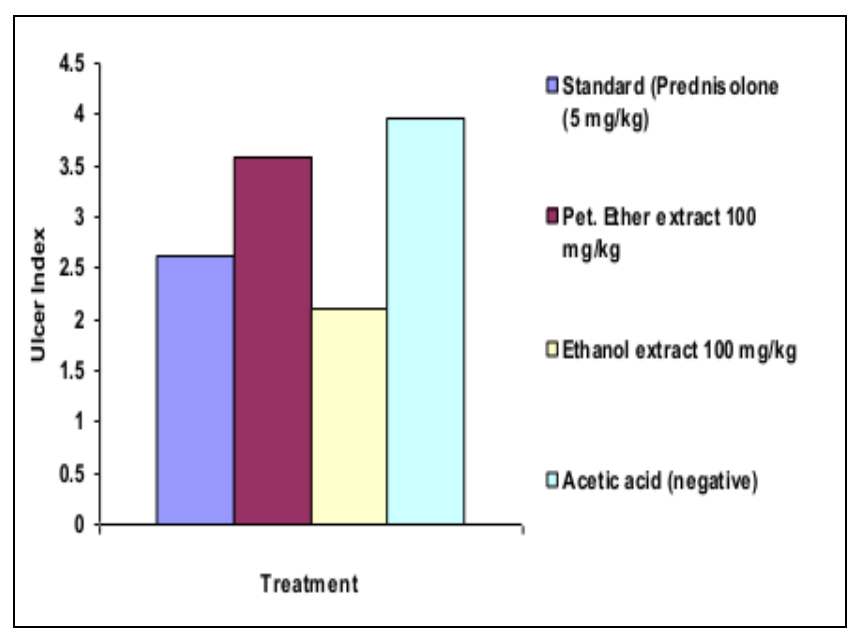

Figure 3: Ulcer Index of various extracts 
Table 4: Qualitative Myeloperoxidase activity of the colon tissues

\begin{tabular}{|c|c|}
\hline Treatment Group & $\begin{array}{c}\text { Myeloperoxidase } \\
\text { activity }\end{array}$ \\
\hline Standard Prednisolone $(5 \mathrm{mg} / \mathrm{kg})$ & ++ \\
Pet. Ether extract $100 \mathrm{mg} / \mathrm{kg}$ & +++ \\
Ethanol extract $100 \mathrm{mg} / \mathrm{kg}$ & ++ \\
Control Acetic acid (negative) & ++++ \\
+ +: damage/ active changes up to less than $25 \%$ \\
++ damage/ active changes up to less than $50 \%$ \\
+++ damage/ active changes up to less $75 \%$ \\
++++ damage/ active changes up to more than $75 \%$
\end{tabular}

Table 5: Quantitative Myeloperoxidase activity of the colon tissues

\begin{tabular}{|l|c|c|}
\hline $\begin{array}{c}\text { Treatment } \\
\text { Group }\end{array}$ & $\begin{array}{c}\text { Myeloperoxidase } \\
\text { activity in Blood } \\
\text { U/ ml }\end{array}$ & $\begin{array}{c}\text { Myeloperoxidase } \\
\text { activity in tissue } \\
\text { U/ ml }\end{array}$ \\
\hline $\begin{array}{l}\text { Stand. } \\
\text { Prednisolone } \\
\text { (5 mg/kg) }\end{array}$ & 242 & 322 \\
\hline $\begin{array}{l}\text { Pet. Ether } \\
\text { extract 100 } \\
\text { mg/kg }\end{array}$ & 324 & \\
\hline $\begin{array}{l}\text { Ethanol extract } \\
100 \text { mg/kg }\end{array}$ & 260 & 360 \\
\hline $\begin{array}{l}\text { Control Acetic } \\
\text { acid (negative) }\end{array}$ & 362 & 332 \\
\hline
\end{tabular}

Observations: Significantly normal activity seen with ethanol extract than petroleum ether extract, showed lower the values of this parameter as compared to other groups.

\section{RESULTS AND DISCUSSION}

Histopathological observation showed ulceration, hyperemia, necrosis, edema, cellular infiltration and goblet cell hyperplasia in the colon of mice treated with acetic acid. Treatment with ethanol extract of Pueraria tuberosa showed least ulceration and hyperemia (Table 2, Figure 2). Result from ulcer index showed better protective effect by ethanol extract of Pueraria tuberosa (Table 3).

Acetic acid caused increase in MPO level in blood and tissue up to $362 \mathrm{U} / \mathrm{ml}$ and $375 \mathrm{U} / \mathrm{mg}$, respectively. After treatment with ethanol extract of Pueraria tuberosa, the MPO level in blood and tissue was decreased significantly to $260 \mathrm{U} / \mathrm{ml}$ and $332 \mathrm{U} / \mathrm{mg}$ respectively. Significant dose dependent reduction was observed after treatment with individual extract.

As ethanol extracts of Pueraria tuberosa root reduced MPO levels significantly, it may have potential anti-inflammatory role in the treatment of colitis because MPO is involved in the inflammatory reaction in colitis. Cytokines are responsible for modulating intestinal inflammation and injury. Increased levels of TNF- $\alpha$ and PGE2 may cause epithelial cell necrosis, edema, and neutrophil infiltration, as proved by the histopathological study. Recently Stucchi et al. (2006) found that LITAF (lipopolysaccharide-induced TNF- $\alpha$ factor), which mediates TNF- $\alpha$ expression in human macrophages, is significantly elevated above controls in macrophages of ileal and colonic tissues from patients with either CD or UC. Elevated levels of PGE2, goes in harmony with Otani et al. (2006) who proved that the increased level of PGE2 is attributed to its enhanced synthesis rather than reduced catabolism, both of which are mediated by TNF- $\alpha$. On the other hand extracts of $\mathrm{M}$. oleifera roots decreased significantly the gross lesion scores, and may be production of TNF- $\alpha$ and PGE2. Inhibition of PGE2, on the other hand, may follow that of TNF- $\alpha$, or may result from its ability to inhibit cycloxygenase enzymes. Since the intestine is in a constant state of controlled inflammation, thus amplification of the inflammatory response activates infiltration of inflammatory cells that triggers pathological responses and symptoms of IBD. Our study showed that acetic acid raised the levels of colonic MPO, indicating infiltration of neutrophils and perturbation of the inflammatory system. This fact is documented in both animal models and patients with IBD. In IBD, oxidative stress plays a role in disease initiation and progression. Reactive oxygen species (ROS) attack the cellular macromolecules, thus disrupting epithelial cell integrity and hindering mucosal recovery, especially in case of impaired endogenous defense systems. In this work, acetic acid induced ROS formation is inhibited by ethanol extracts of Pueraria tuberosa root are proved as good antioxidant, thus, its ability to inhibit free radical generation, as was proven in this work by restoring the redox state of the colonic mucosa, offers another explanation of the antiulcerogenic activity of this plant.

Ethanol extracts of Pueraria tuberosa root ameliorated neutrophil infiltration as evidenced by suppression of colon MPO and improvement of histological features. This action lends pharmacological support to folkloric, ethno-medical uses of the plant in the management of inflammatory GIT disorders.

\section{CONCLUSION}

The present antiulcer activity of petroleum ether and ethanolic extracts of tuber of pueraria tuberosa roxb in albino rats showed significant effect.

\section{ACKNOWLEDGEMENT}

The authors are extremely grateful to the Smt. S. S. Patil College of Pharmacy, Chopda, Maharshtra, India for providing financial support (faculty research) and research facilities to accomplish this study. 


\section{REFERENCES}

1. Akhtar MS, Akhtar AH, Khan MA. Antiulcerogenic effects of Ocimum basilicum extracts volatile oils and flavonoid glycosides in albino rats, Int J Pharmacognosy, 1992;30(2):97-104.

2. Goel RK, Bhattacharya SK. Gastroduodenal mucosal defence and mucosal protective agents, Indian J Exp Biol, 1991; 29(2):701-14.

3. Laine L, Takeuchi K, Tarnawski A. Gastric mucosal defense and cytoprotection: Bench to bedside, Gastroenterology, 2008; 135(1):41-60.

4. Thomas, J. Medicinal and aromatic plants research in India. In UNDP. Proc. Training course on Industrial Exploitation of Indigenous Medicinal and Aromatic Plants. Eijing, China, 1997;2(3):17-27.

5. Karthikeyan, A, V Shanthi, A Nagasathaya. Preliminary phytochemical and antibacterial screening of crude extract of the leaf of Adhatoda Vasica L, Int. J.Green Pharm., 2009; 3(4): 78-80.

6. Diallo, D, B Hveem, M A Mahmoud, G Betge, B S Paulsen and A. Maiga. An ethnobotanical survey of herbal drugs of Gourma district, Mali. Pharmaceutical Biology, 1999; 37(2): 80-91.

7. Laloo, R. C, L Kharlukhi, S Jeeva, B P Mishra. Status of medicinal plants in the disturbed and the undisturbed sacred forests of Meghalaya, northeast India: population structure and regeneration efficacy of some important species, Curr Sci., 2006;90(2):225-232.

8. Kirtikar, K. R. and B. D. Basu. Indian Medicinal Plants, $2^{\text {nd }}$ ed.; The Indian Press, Allahabad 1988.

9. Bhutani, S P, S S Chibber and T. Seshadri. Indian J. Chem, 1969;7(3):210.

10. Babu, PV, Rao, MA, Kumar, SMS, Rao, NV. A study on adaptogenic activity of tuber extracts of Pueraria tuberose, Indian Drugs, 2006;43(6):486-92.

11. Danaei, G, Finucane, M.M, Lu, Y, Singh, G.M, Cowan, M.J, Paciorek, CJ.et al. National, regional, and global trends in fasting plasma glucose and diabetes prevalence since 1980: systematic analysis of healthexamination surveys and epidemiological studies with 370 country-years and 2.7 million participants. Lancet, 2011;378(9785):31-40.
12. Khandelwal, K.R. Practical Pharmacognosy, $9^{\text {th }}$ ed., Nirali Prakashan 2002;45-56.

13. Khare, CP. Indian medicinal plants: An illustrated dictionary, New York: Springer Science, 2008;527.

14. Kokate, CK Practical Pharmacognosy, $3^{\text {rd }}$ ed, Vallabh Prakashan, Delhi,1994;115-127.

15. Prakash, AO, Saxena, V, Shukla, S, Mathur, R. Contraceptive potency of Pueraria tuberosa D.C. and its hormonal status, Acta Eur Fertil, 1985;16(1):59-65.

16. Pramanik, SS. Antioxidant and antistress activities of standardized Pueraria tuberosa (roxb. ex willd.) dc tuber root extract in wistar rats, Inventi Rapid: Ethnopharmacology, 2010;144(3):22-26.

17. Raghuwanshi, R and Jain, B. Hypoglycemic effect of Pueraria tuberosa tubers in healthy and alloxan diabetic Rats, J. Chem. Bio. Phy. Sci., 2012;2(1):270272.

18. Roglic, G, Unwin, N. Mortality attributable to diabetes: estimates for the year 2010. Diabetes Res Clin. Pract., 2010;87(3):15-19.

19. World Health Organization. Definition, diagnosis and classification of diabetes mellitus and its complications. Part 1: Diagnosis and classification of diabetes mellitus. Geneva, (WHO/NCD/NCS/99.2), 1999.

20. Ana Guedes Martins, Sílvia Stanisçuaski Guterres \& George Gonzalez Ortega, Anti-ulcer Activity of Spraydried Powders prepared from Leaf Extracts of Maytenus ilicifolia Martius ex Reiss, Acta Farm. Bonaerense. 2003;22(1):39-44.

21. Das D, Banerjee R. Effect of stress on the antioxidant enzymes and gastric ulceration, Mol and Cell Biochem., 2003;125(2):115-25.

22. Dashputre NL, Naikwade NS, Evaluation of Anti-Ulcer Activity of Methanolic Extract of Abutilon indicum Linn in Rats, International Journal of Pharmaceutical Sciences and Drug Research, 2011;3(2):97-100.

23. Deshpande SS, Saha GB, Parmar NS, Antiulcer activity of Tephrosia purpurea in rats, Indian Journal of Pharmacology, 2003;35(3):168-172.

24. Deshpande SS, Shah GB, Parmar NS. Antiulcer activity of $T$. purpurea in rats, Indian J. Pharmacol., 2002;34(2):144.

\section{Source of Support: None declared.}

Conflict of Interest: None declared.

For any question relates to this article, please reach us at: editor@globalresearchonline.net

New manuscripts for publication can be submitted at: submit@globalresearchonline.net and submit_ijpsrr@rediffmail.com 